\title{
EDITORIAL
}

\section{0: THE YEAR OF THE COVID-19 PANDEMIC}

\author{
J.E. MORLEY
}

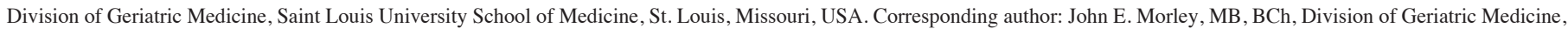

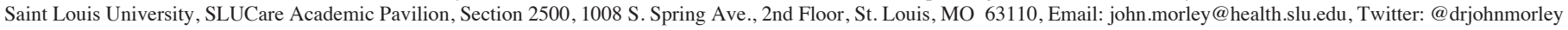

Key words: COVID-19, coronovirus, pandemic, elderly.

"There have been as many plagues as wars in history; yet always plagues and wars take people equally by surprise."

The Plague

Albert Camus

The first recorded plague was the Plague of Athens in 430427 BC. It was most probably due to measles. Thucydides noted that "There was a particularly high mortality among doctors." The next pandemic was the Antonine Plague (165180 AD). It was caused by smallpox and killed over 6 million persons. It destroyed the economy and made politics chaotic. Smallpox was eventually eradicated by 1980 . Together with smallpox, two other infectious diseases, cholera and the black death (Yersinia pestis) were the major causes of pandemic until the twentieth century. In 1918-20 the "Spanish" influenza, which actually started in Camp Funston in Kansas, was caused by H1N1 influenza A virus and killed between 20 to 50 million persons worldwide. Subsequently, a number of other influenza epidemics occurred during the 20th and 21 st century. Other epidemics in the 20th century include polio, human immunodeficiency virus infection (HIV/AIDS), Ebola, the Marburg virus and the Zika virus.

In 1967, Dr. Ken McIntosh identified the coronavirus as a cause of the common cold. Subsequently, 2 coronaviruses with high death rates, viz severe acute respiratory syndrome (SARS) and Middle East Respiratory Syndrome, were identified in the 21 st century. At the end of 2019 coronavirus disease (COVID19) transferred from bats to humans in Wuhan in China. From here, one strain spread to Milan and then New York and another strain to the west coast of the USA.

COVID-19 has worse outcomes in older persons especially if they are frail (1-3). Persons with hypertension, diabetes mellitus, and heart failure also have worse outcomes. Just under half of persons with COVID-19 are asymptomatic (4). The presentations of COVID-19 are protean involving almost every part of the body (Figure 1). Older persons often have no fever and present with delirium, reduced mobility, falls and muscle wasting (5-7). The increase in inflammatory cytokines and anorexia can lead to severe cachexia (8). Persons with dementia fail to understand the social isolation and become confused, delirious, fearful, helpless, angry, and depressed (9).
This places stress on caregivers $(10,11)$. It is important to avoid physical restraints $(10,11)$.

Figure 1

Clinical Presentations of COVID-19

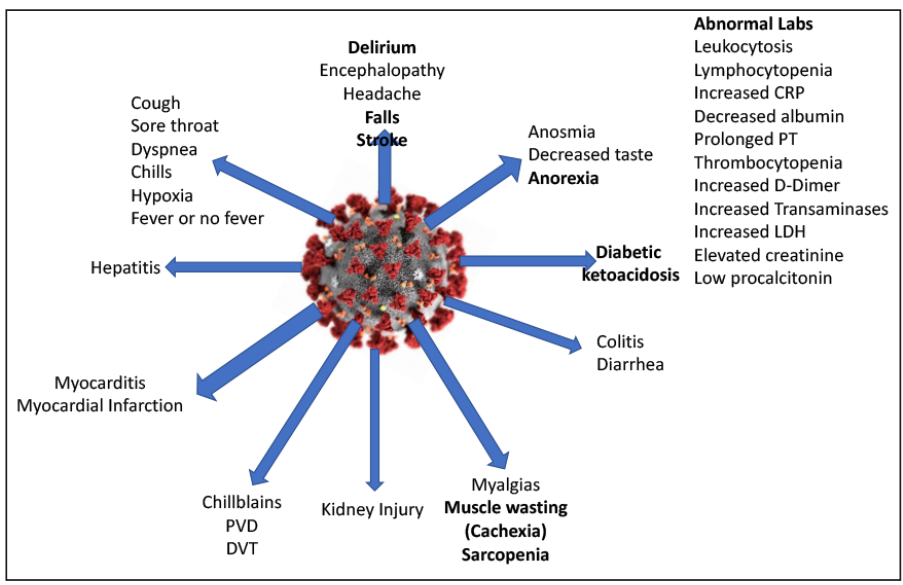

The diagnosis of COVID-19 is made by the polymerase chain reaction which is $97 \%$ accurate and detects those who are infected (12). The antigen test detects the viral nucleocapsid protein, but has had variable accuracy. A new CRISPR test has been developed (13). Antibody tests (IgG and IgM) detect those who have had an infection.

A number of drugs have had variable effects in improving outcomes in persons with COVID-19 (Table 1)(14-16). Selfproning has decreased the number of people who need to be ventilated (17). Prevention requires remaining at least 6 feet (2 meters) apart, wearing a mask and washing ones hands (18). It is important to recognize wearing a mask protects others much more than wearers. Part of the failure of the USA to control COVID-19 has been the failure of its leadership to encourage these practices. Many older persons lip read and masks block this ability: Transparent mouth masks have been developed to overcome this problem. 
Table 1

Medications used for COVID-19

\begin{tabular}{ll}
\hline 1. & Dexamethasone \\
2. & Remdesivir (no effect on mortality) \\
3. & Baricitinib (Janus kinase inhibitor) \\
4. & ?Convalescent serum \\
5. & ?Antibodies \\
6. & ?Antisense \\
\hline
\end{tabular}

Nursing homes have proven to be the most vulnerable site for COVID-19 infections $(19,20)$. Obviously, persons in nursing homes are old with multiple comorbidities. It is hard to isolate persons in nursing homes. Caregivers who work in nursing homes are poorly paid and often live in vulnerable communities, increasing the chance of introducing COVID19 into the long term care venue. Lack of personal protective equipment and a failure to test staff and patients further lead to spread of the virus in this "high touch" environment. Many hospitals sent untested patients with COVID-19 directly to the nursing homes, further spreading the disease.

It is important to recognize that COVID-19 can require prolonged rehabilitation even in those not ventilated. Alfonso Jose Cruz Jentoft, a geriatrician, described his recovery as such:

"Exhausted. Every day I got a little better. Eventually I could walk over an hour at home. At first I couldn't climb a flight of stairs without stopping. Little by little I came to do three stairs in a row - yes drowned and desaturated. I improved slower than what I would want. Trying to gain weight."

It is well recognized that some persons with viral diseases, such as infectious mononucleosis, can have a post viral syndrome that can linger for at least a year (21). There is clearly a "long Covid" syndrome that can linger for a prolonged period of time $(22,23)$. The features of this syndrome are outlined in Table 2 .

The eventual control of COVID-19 will depend on the development of a safe, functional vaccine. Numerous types of vaccines are being developed including a viral vector, an inactivated vaccine, a DNA or RNA molecule, a subunit and a live attenuated vaccine (24). A major problem exists with the "Anti-Vaxers." At least one third of Americans have no intention of being vaccinated.

Lockdowns have been widely used in an attempt to limit the spread of the virus. These lead to social isolation. We already have a loneliness epidemic and the COVID-19 era has clearly aggravated this $(25,26)$. Loneliness leads to depression, sleep problems, cognitive impairment, a decline in function, poor quality of life, cardiovascular disease, increased hospitalization and increased mortality. In addition, lockdown has led to a decrease in exercise which results in an acceleration of sarcopenia. The importance of loneliness was heightened by Vivek Murthy, a former surgeon general of the USA, who said, "During my years caring for patients, the most common pathology I saw was not heart disease or diabetes; it was loneliness." (27). All older persons should be screened for sarcopenia utilizing SARC-F (28-31), and those who are positive should be referred to an exercise program such as ViviFrail (32). Isolation has also led to an increase in elder abuse (33).

Table 2

Effects of "long covid" syndrome

\begin{tabular}{ll}
\hline 1. & Dyspnea \\
2. & Cough \\
3. & Confusion \\
4. & Fatigue \\
5. & Red eyes \\
6. & Anorexia \\
7. & Dysgeusia \\
8. & Chest pain \\
9. & Autonomic neuropathy \\
10. & Postural orthostatic tachycardia \\
11. & Kidney failure \\
12. & Joint pains \\
13. & Myalgia \\
14. & Sarcopenia \\
15. & Falls \\
\hline
\end{tabular}

Because of the isolation of persons who often die from COVID-19, there has been a number of bereaved individuals who have developed traumatic stress due to not being able to be with their loved ones during the dying period. This prolongs the grief period (34).

It needs to be recognized that COVID-19 has given us some of the worst examples of ageism. Robert Butler (35) defined ageism as a form of bigotry where younger persons demonstrate prejudicial attitudes towards older adults, old age and the aging process leading to discriminatory practices against older persons. Hostile ageism has been demonstrated by characterizing COVID-19 as the "boomer remover" and in Italy where chronological age-based cutoffs were used to ration ventilators, i.e., distribute justice. Neglectful ageism was shown by many healthy young persons ignoring recommendations to socially isolate and protect their older relatives. An example of benevolent ageism was when the governor of Texas said that older persons (including himself) would volunteer to die so Americans "don't lose our whole country." It needs to be remembered that many older persons play a highly functional role in our society, e.g., Queen Elizabeth, Pope Francis and the Dalai Lhama. Also the oldest person to survive COVID-19 was 113 year old Maria Brunyas from Spain. At 107 Marilee Asher 


\section{THE JOURNAL OF NUTRITION, HEALTH \& AGING}

survived COVID-19 after having survived the 1918 "Spanish flue" pandemic.

For most of us, 2020 was an existential torture. We all hope that in 2021, the storm will pass and with the help of vaccines, the sun will shine again. I conclude this editorial with a bedtime story for your grandchildren:

Imagine: A bedtime story for your grandchildren

Imagine when the world was covered by pollution,

Not a star could be seen in the sky,

White Americans shot young black men for fun,

A wall was built to keep immigrants out,

The UK BREXITED from the EU,

Ageism and Racism were common,

Children starved throughout the world,

Middle aged people in USA died from obesity,

The ruler in Saudi Arabia had a journalist killed and few cared,

From Yemen and African to beyond, people fought wars,

A little man in North Korea threatened to start a nuclear war.

\section{Things could get worse}

When a small virus with a crown swept around the world killing large numbers of people,

Some called it the "boomer remover,"

Others just said no ventilators for the old,

Or said old folks will die to save the young,

People isolated in their houses and some became depressed,

We masked and didn't come within 2 meters of one another... well a few did,

Pollution disappeared,

Others got guns and protested that they should not need to stay home to save old people,

There was not enough PPE for health providers,

There was an economic crisis with no people working,

Many could not afford food,

Those who already had 3 or more guns went out to buy more to shoot the little virus,

Politicians blamed everyone but themselves.

\section{And then came a vaccine}

People no longer stayed inside

People no longer wore masks or socially distanced,

People were much nicer to one another,

People used electric cars and flew less to keep pollution away,

People were excited to go to football games.

\section{But then}

They went back to being as they were before,

Self-centered,

Not caring about others,

And the world was sad again.
Disclosures: The author declares there are no conflicts.

\section{References}

1. Chinnadurai $\mathrm{R}$, Ogedengbe $\mathrm{O}$, Agarwal $\mathrm{P}$, et al. Older age and frailty are the chief predictors of mortality in COVID-19 patients admitted to an acute medical unit in a secondary care setting - a cohort study. BMC Geriatr 2020;20:409. Doi: 10.1186/ s12877-020-01803-5.

2. Kundi H, Ozcan Cetin EH, Canpolat U, et al. The role of frailty on adverse outcomes among older patients with COVID-19. J Infect 2020;Sep 28;S0163-4453(20)30636-8.

3. Hagg S, Jylhava J, Wang et al. Age, frailty, and comorbidity as prognostic factors for short-term outcomes in patients with coronavirus 2019 in geriatric care. J Am Med Dir Assoc 2020;Aug 14:DOI. 10.1016/j.jamda.2020.08.014. [Epub ahead of print].

4. Kault D. Superspreaders, asymptomatics and COVID-19 elimination. Med J Aust 2020; Oct 24. Doi.105694/mja2.50835. [Epub ahead of print].

5. Sacco G, Briere O, Asfar M, et al. Symptoms of COVID-19 among older adults: A systematic review of biomedical literature. Geriatr Psychol Neuropsychiatr Vieil 2020; 18:135-139.

6. Cesari M, Proietti M. Editorial: Geriatric medicine in Italy in the time of COVID-19. J Nutr Health Aging 2020;24:459-460.

7. Abbetacola AM, Antonelli-Incalzi R. Editorial: COVID-19 spiraling of frailty in older Italian patients. J Nutr Health Aging 2020;24:453-455.

8. Morley JE, Kalantar-Zadeh K, Anker SD. COVID-19: A major cause of cachexia and sarcopenia? J Cachexia Sarcopenia Muscle 2020;11:863-865

9. Dening $\mathrm{KH}$, Lloyd-Williams M. Minimising long-term effect of COVID-19 in dementia care. Lancet 2020;Oct 3;396(10256):957-958. Doi: 10.1016/S0140 6736(20)32024-9.

10. Mazzi MC, Iavarone A, Musella C, et al. Time of isolation, education and gender influence the psychological outcome during COVID-19 lockdown in caregivers of patients with dementia. Eur Geriatr Med 2020;Oct 14;1-4.

11. Migialaccio R, Bouzigues A. Dementia and COVID-19 lockdown: More than double blow for patients and caregivers. J Alzheimers Dis Rep 2020;Jul 6;4:231-235.

12. Morley JE, Vellas B. Editorial: COVID-19 and older adults. J Nutr Health Aging 2020;24:364-365.

13. Dhamad AE, Rhida MAA. Covid019: Molecular and serological detection methods. Peer J 2020;8:e10180. Doi.10.7717/peer.10180. eCollection 2020.

14. Horby P, Lin WS, Emberson JR, et al. Dexamethasone in hospitalized patient with Covid-19 - preliminary report. N Engl J Med 2020;Jul 17;NEJMoa2021436. Doi.10.1056/NEJMo12021436. [Epub ahead of print].

15. Dyer O. Covid19: Remdesevir has little or no impact on survival, trial shows. BMJ 2020; Oct 19;371:m4057.

16. Gupta A, Karki R, Dandu HR, et al. COVID-19: Benefits and risks of passive immunotherapeutics. Hum Vaccin Immunother 2020;Sep 22;1-10. Doi.10.1080/2164 5515.2020.108410. [Epub ahead of print]

17. Sztajnbok J, Maselli-Schoueri JH, de Resende Brasil LMC, et al. Prone positioning to improve oxygenation and relieve respiratory symptoms in awake, spontaneously breathing non-intubated patients with COVID-19 pneumonia. Respir Med Case Rep 2020;30:101096.

18. Chhetri JK, Chan P, Arai H, et al. Prevention of COVID-19 in older adults: A brief guidance from the International Association for Gerontology and Geriatrics (IAGG) Asia/Oceania region. J Nutr Health Aging 2020;24:471-472.

19. Wasserman M, Ouslander JG, Lam A, et al. Editorial: Diagnostic testing for SARSCoronavirus-2 in the nursing facility: Recommendations of a Delphi Panel of longterm care clinicians. J Nutr Health Aging 2020:24:538-443.

20. Rolland Y, Lacoste MH, de Mauleon A, et al. Guidance for the prevention of the COVID-19 epidemic in long-term care facilities: A short-term prospective study. J Nutr Health Aging 2020;24:812-816.

21. Hickie I, Davenport T, Wakefield D, et al. Post-infective and chronic fatigue syndromes precipitated by viral and non-viral pathogens: Prospective cohort study. Brit Med J 2006;333:575.

22. Morley JE. COVID-19 - the long road to recovery. J Nutr Health Aging 2020; Oct 5. https://link.springer.com/article/10.1007/s12603-020-1473-6.

23. Greenhalgh T, Knight M, A'Court C, et al. Management of post-acute covid-19 in primary care. BMJ 2020;370:m3026. Doi: https://doi.org/10.1136/bmj.m3026.

24. Haynes BF, Corey L, Fernandes P, et al. Prospects for a safe COVID-19 vaccine. Sci Transl Med 2020;Oct 19. Doi.10.1126/scitranslmed abe0948. [Epub ahead of print].

25. Berg-Weger M, Morley JE. Editorial: Loneliness and social isolation in older adult during the COVID-19 pandemic: Implications for gerontological social work. J Nutr Health Aging 2020;24:456-458.

26. Berg-Weger M, Morley JE. Editorial: Loneliness in old age: An unaddressed health problem. J Nutr Health Aging 2020;24:243-245

27. Murthy VH. Together. Harper Wave; New York, 2019.

28. Malmstrom TK, Miller DK, Simonsick EM, et al. SARC-F: A symptom score to predict persons with sarcopenia at risk for poor functional outcomes. J Cachexia Sarcopenia Muscle 2016;7:28-36.

29. Bahat G, Yilmaz O, Kilic C, et al. Performance of SARC-F in regard to sarcopenia definitions, muscle mass and functional measures. J Nutr Health Aging 2018:22;898- 


\section{0: THE YEAR OF THE COVID-19 PANDEMIC}

903

30. Ha Y-C, Won Won C, Kim M, Chun K-J, Yoo J-I. SARC-F as a useful tool for screening sarcopenia in elderly patients with hip fractures. J Nutr Health Aging 2020;24(1):78-82.

31. Cao L, Chen S, Zou C, et al. A pilot study of the SARC-F scale on screening sarcopenia and physical disability in the Chinese older people. J Nutr Health Aging 2014;18:277-283.

32. Izquierdo M, Rodriguez-Manas, Sinclair AJ. Editorial: What is new in exercise regimes for frail older people - how does the Erasmus Vivifrail project take us forward? J Nutr Health Aging 2016;20(7):736-737.
33. Elman A, Breckman R, Clark S, et al. Effects of the COVID-19 outbreak on elder mistreatment and response in New York City: Initial lessons. J Appl Geronto 2020;39(7):690-699.

34. Stroebe M, Schut H. Bereavement in times of COVID-19: A review and theoretical framework. Omega (Westport) 2020;Oct 21;30222820966928. DOI: $10.1177 / 0030222820966928$

35. Butler RN. Age-ism: Another form of bigotry. Gerontologist Winter 1969;9(4):243246. Doi.10.1093/geront/9.4_part_1.243. 